\title{
Intervention sensu Wilson: The only valid approach to microbiological safety of food
}

Hitherto, outbreaks of infectious diseases and microbial intoxications transmitted by foods in The Netherlands were, as a rule, limited and without serious consequences. Sometimes they were on a larger scale, but still benign, and only seldom have such incidents resulted in the death of any patients. However, the small epidemic of shigellosis associated with the consumption of shrimp cocktail made from frozen produce imported from the Far East that occurred in December 1983 and January 1984 had the tragic score of 14 deaths in one exposed group of about $100[16]$.

Between December 25th 1983 and January 7th 198459 cases of dysentery bacteriologically proven to be caused by Shigella flexneri 2 occurred in The Netherlands. For a further 34 cases of gastroenteritis. strong epidemiological evidence was present to allow the diagnosis of shigellosis. In approximately 80 additional cases of gastroenteritis the disease was probably also caused by Shigella (Bijkerk, $\mathrm{H}_{\text {., personal }}$ communication, 18th January 1984). The epidemic caused death in 14 patients, all aged over 70 . The earliest sign of the epidemic came from a home for elderly people. 28 of the 208 residents and 2 of the 22 staff fell ill with fever and gastroenteritis.

The shrimp cocktail served at the Christmas dinner was suspected to be the source of infection. The history of other patients substantiated the aetiological role of the shrimps. The incriminated shrimps were imported in a peeled and frozen condition from the Far East. Subsequent bacteriological examination of shrimps presumably or alledgedly of the same shipment has, so far, failed to demonstrate the presence of Shigella flexneri. Lack of success is. of course, not unusual in attempts to isolate a sensitive pathogenic organism from a probably aetiologically involved food some time after an incident has occurred [3,15].

Rather than endless discussions of what and who went wrong in this deplorable outbreak, a lesson for the future should be learned. Fortunately there is little room for disagreement amongst medical microbiological experts in this instance.

\section{Epidemiological surveillance}

Prevention of any infectious disease is impossible when valid epidemiological data are lacking. Therefore, epidemiological alertness is the first priority.

When a group of persons sharing the same meal fall sick almost simultaneously, demonstrating very similar symptoms, whereas their partners or friends refraining from a given item remain healthy, then there is reason for suspecting a food-borne incident. Bacteriological and cytological examination of patients' stools coupled with a review of the epidemiological record of the probably incriminated meal item will 
soon substantiate or disprove the initial hypothesis.

Nonetheless, it must be emphasized that meal samples examined later, or at the time, have to be epidemiologically valid. They are accepted as valid only if their bacterial colonisation resembles the colonisation of the food eaten in both the quantitative and the qualitative sense [3].

\section{Methods of control}

In many instances, the approach to remedying a dangerous situation is far from perfect. Too frequently reliance is placed on control by montitoring - an ingrained habit that has repeatedly been demonstrated to be ineffective $[8,17,4.5 .9]$. Sample examination of consignments of food in attempts to identify microbiologically safe lots is a fruitless procedure from the statistical point of view [9], and is also of little value as a prevention strategy. Examination of food samples is not only time consuming but also costly. Moreover, it requires experience which is not always available as in the tragic shigellosis outbreak which prompted this note, in which a rather unusual exotic pathogen, i.e. Shigella flexneri type 2, was involved. Finally, when monitoring reveals that the commodity is in a potentially hazardous condition. it has to be treated by decontamination anyway. Why then, is this not applied systematically in the standard manufacture?

As repeatedly emphasised by experienced public health bacteriologists $[8,17,4,5,18]$, what is actually required is intervention $[10,14]$ based on the identification of hazard points [1] in the manufacture or culinary preparation of the incriminated item. In the case of frozen oriental shrimps this is obviously recontamination, from the severely contaminated local environment, after the previous decontamination by cooking [2]. Such occurrences of post-processing recontamination bear a sporadic and erratic character [12,14]. Monitoring of lots to separate the safe from the unsafe is, therefore. totally unreliable. The commodity should, as in the case of raw milk or raw egg products [18,14], be processed for safety before it reaches the consumer.

In the case of shrimps imported from areas where enteric infections of a bacterial and viral nature are endemic this can be achieved by heat treatment (pasteurisation) directed at the shrimp surface [20], by irradiation with a suitable dose of $\gamma$-radiation $[12,7]$ linked to avoiding recontamination by hygienic plant and manufacturing conditions and hermetic packaging. Once this mode of intervention has been introduced, monitoring of lots becomes functional, now being aimed at validation of the decontamination process applied.

\section{Epicrisis}

As emphasised before, the concept of intervention is at least 50 years old, but has only been applied in exceptional cases. It may sound rhetorical, but it is sincerely hoped that the death of 14 people in Utrecht may not have been without benefit for 
the protection of millions of consumers worldwide. The valid approach can hardly be better summarised than Sir Graham Wilson did, over 30 years ago: "We must keep asking ourselves whether any measure we should like to introduce would in fact appreciably diminish the incidence of ... food-borne disease. When I look back on some of the great food-poisoning outbreaks with which I have been associated I sometimes wonder whether any routine bacteriological tests ... would have prevented them: and I continue to wonder. It is ... in my opinion ... far more important to lay down a strict code for the ... processing of food and see that it is carried out properly than to rely on bacteriological sampling of the finished product" $[18,19]$.

Adopting Sir Graham's inquisitive attitude, it seems obvious that outbreaks like the Utrecht shigellosis disaster are preventable in future. It requires ensuring that any food product offered to elderly consumers whose already reduced defence against pathogens may be further impaired by emotional instability, e.g. around Christmas [11,6,13], has been processed for safety, hermetically packed and stored at temperatures below $7^{\circ} \mathrm{C}$, because it is than as safe as pasteurised milk [14].

A. Kayser

Sint Antonius Ziekenhuis

Niewegein

The Netherlands
D.A.A. Mossel

Vakgroep Voedingsmiddelen van Dierlijke Oorsprong Fakulteit Diergeneeskunde Rijksuniversiteit Utrecht The Netherlands

\section{References}

[1] Bauman. H.E., 1974. The HACCP concept and microbiological hazard categories. Food Technol. 28 , No. 9. 30-34;74.

[2] Beckers, H.J., M. van Schothorst, K.J.A. van Spreekens, and J.J. Oosterhuis, 1981. Microbiological quality of frozen precooked and peeled shrimp from South-East Asia and from the North Sea. Zentralbl. Bakteriol. Hyg..I.Orig., B. 172. 401-410.

[3] Bouwer-Hertzberger. S.A. and D.A.A. Mossel. 1982. Bacterioscopic examination of specimens possibly involved in diseases of bacteriol etiology transmitted by foods. In:Isolation and Identification Methods for Food Poisoning Organisms, edited by J.E.L. Corry, D. Roberts and F.A. Skinner. Academic Press, London, pp. 25-33.

[4] Cheftel, H., 1955. Remarques à propos du controle bactériologique des jambons conservés en boîtes. Ann. Inst. Pasteur Lille 7. 256-262.

[5] Dack, G.M., 1956. Evaluation of microbiological standards for foods. Food Technol. 10, 507-509.

[6] Haas, C.N., 1983. Estimation of risk due to low doses of microorganisms: a comparison of alternative methodologies. Am. J. Epidemiol. 118, 573-582.

[7] Kampelmacher, E.H., 1983. Irradiation for control of Salmonella and other pathogens in poultry and fresh meats. Food Technol. 37. No. 4, 117-119;169.

[8] Meyer, K.F., 1931. The protective measures of the State of California against botulism. J. Prevent. Med. 5, $261-293$.

[9] Mossel, D.A.A. and E.F. Drion. 1958. Sampling of canned foods for bacteriological analysis. Food $27.333-337$.

[10] Mossel, D.A.A. and E.H. Kampelmacher, 1981. Prevention of salmonellosis. Lancet ii, 208.

[11] Mossel, D.A.A., G. Gaikhorst and E.C. Carbasius Weber, 1982. Food-transmitted infections and 
intoxications in hospitals. Aetiological principles and essentials of control. Suiss Med. 4. No. 3 a. $19-41$.

[12] Mossel, D.A.A. and P. van Netten, 1982. Whither protection of the consumer against enteropathogenic bacteria on fresh meats and poultry by processing for safety. In: Food Irradiation Nou. Martinus Nijhoff. The Hague and Boston, pp. 2-19.

[13] Mossel, D.A.A. and H. van der Zee. 1983. Agar immersion plating and control ("dip") slides. Their use in the safety assurance of meals with particular reference to those served to elderly or compromised consumers. Swiss Food 5. No. 6. 20-21.

[14] Mossel, D.A.A., 1984. Intervention as the rational approach to control diseases of microbial etiolog: transmitted by foods. J. Food Safety 6 , in press.

[15] Tacket. C.O.. J.P. Larain. R. Sattin. J.P. Lofgren. C. Konigsherg. R.C. Rendtorff. A. Rausa. B.R. Davis and M.L. Cohen. 1984. A multistate outbreak of infections caused by Versinia enterecoliticat transmitted by pasteurized milk. J. Am. Med. Assoc. 251. 483-486.

[16] Verhoef, J., A. Kayser and D.A.A. Mossel. 1984. Shigellosis - a reminder prompled by a recent outbreak in The Netherlands. Nederl. Tijdschr. Geneeskd. 128, in press.

[17] Wilson. G.S. (1933) The necessity for a safe milk supply. Lancet ii. 829-832.

[18] Wilson. G.S. 1955. Symposium on food microbiology and public health: general conclusion. J. Appl. Bacteriol. 18. 629-630.

[19] Wilson. G.S., 1973. Introductory address. In: The Microbiological Safety of Food. edited by B.C. Hobbs and J.H.B. Christian. Academic Press, London. pp. xi-xii.

[20] Woolthuis. C.H.J. D.A.A. Mossel. J. van Logtestijn. J.M. de Krujif and F.J.M. Smulders. 1984. Microbial decontamination of porcine liver with lactic acid and hot water. J. Food Protect. 47. in press. 